\title{
SUETONIUS AND HIS TREATMENT OF THE EMPEROR DOMITIAN'S FAVOURABLE ACCOMPLISHMENTS
}

\author{
Geoff W. Adams
}

\begin{abstract}
Suetonius has become one of the most influential and important ancient sources for our understanding of the socio-political climate in First Century Imperial Rome and the personalities of its emperors. However, he has illustrated in his texts a bias, often in a subtle manner that illustrates the historical and cultural aspects of the literary climate during this period. One notable example is his Life of the Emperor Domitian, which corresponds well with the maturity of Suetonius' writings by this time, but is also unique because of its construction and personal attributes, being the most recent imperial life written by Suetonius. This life illustrates both the literary climate of this period (being clearly influenced by its Senatorial audience) as well as the damning and lasting impressions that the damnatio memoriae has had upon the historical sources on the Emperor Domitian.
\end{abstract}

Suetonius' De Vita Caesarum has been the subject of much discussion, particularly with reference to the bias evident within his biographies. This inquiry focuses upon the Life of Domitian, the prejudices that Suetonius held in this composition, and how apparent such tendencies are throughout his work.

It is clear that this biography was imbued with a fair degree of hostility towards the deceased emperor. Although Suetonius' work was not as vicious as the writings of Tacitus and Pliny, ${ }^{1}$ negative representation of Domitian still pervades his biography. In order to examine this aspect of Suetonius it is necessary to compare the prevailing literary trends of the period, the format of his biography and the nature of his bias. This examination centres upon the inaccuracies that are attributable to the author's prejudice in his Life of Domitian and his compliance with literary trends in the post-Domitianic era.

Suetonius' negative portrayal of emperors was not limited to Domitian. Emperors Tiberius, Gaius, Claudius, Nero and Vitellius also received negative portrayal in accordance with the senatorial influence and damnatio memoriae evident in the literature of the period. ${ }^{2}$ This attitude towards these condemned emperors matched the views of the senatorial aristocracy who were the patrons of literary commissions and their authors. Many authors allowed the élites to influence their writings, as this was one of the ways to gain the prestige a writer required to survive in his occupation. Aristocratic patronage may have been vital for Suetonius' career because it is likely that it was through associations with Pliny and Septicius Clarus ${ }^{3}$, and their social connections, that Suetonius

${ }^{1}$ Baldwin 1983: 299, 302; McDermott, Orentzel 1979: 5; Shotter 1993: 7-8.

2 Jones 1996: XV; Townend 1967: 91.

${ }^{3}$ Plin., Ep. 10.94.1; Duff 1964: 506. 
was able to obtain the positions of ab epistulis, for which outside favour, intellectual, scholastic or literary activity, was essential. ${ }^{4}$

If a deceased emperor was unpopular with the senate the process of damnatio memoriae (condemning the emperor's memory) was often carried out, ${ }^{5}$ even though this has been questioned recently. ${ }^{6}$ Domitian suffered not only in the literary sphere but in all respects having his name removed from all official and private records. ${ }^{7}$ This process has been remarkably pervasive in its imputation of Domitian's character, influencing every account of Domitian's life. Senatorial hatred for Domitian stemmed mostly from his preference for pursuing his own ideals and standards and ignoring the suggestions of the senate. The aristocrats judged many of Domitian's actions to be improper and believed that it was their right to demand imperial recognition for their social status. ${ }^{8}$ The senate considered that the emperor should behave with a degree of restraint and must exhibit respect for the established order. ${ }^{9}$ A dearth of imperial affection toward the senate was quite common but it was Domitian's inability to hide his ambivalence for the senate that infuriated them and led to allegations of Domitian's arrogance. ${ }^{10}$

Suetonius' hostility towards Domitian is not surprising considering the circles in which he socialized; he was closely associated with the senatorial, anti-Domitianic party, of which Pliny was a vocal member: quanto nunc tutior, quanto securior eadem domus, postquam erus non crudelitatis sed amoris excubiis non solitudine et claustris, sed ciuium celebritate defenditur. ${ }^{11}$

Many modern scholars have interpreted Suetonius' loose application of chronology as a sign of questionable scholarship ${ }^{12}$ particularly when this is combined with Suetonius' predilection for gossip. This criticism mostly comes from those who treat Suetonius' work as history instead of biography. ${ }^{13}$ The possibility of Suetonius writing in a careless manner is unlikely. In one of his Epistulae, Pliny refers to Suetonius' tu tamen meam quoque cunctationem tarditatemque... perfectum opus absolutumque est, nec iam splendescit lima sed atteritur, suggesting that Suetonius was more a perfectionist than a reckless writer. ${ }^{14}$ Suetonius' biographical style is more precise than it first seems. His methodology is simply an attempt to combine as many elements of Domitian's life and character as possible, but in a limited sphere. This technique sought to provide what Suetonius deemed

\footnotetext{
${ }^{4}$ Millar 1977: 83, 91; Lounsbury 1979: 41; cf. Lindsay 1994.

${ }^{5}$ See Vittinghoff 1936 for the most comprehensive work on damnatio memoriae. For instances of damnatio memoriae see Wood 1983, Pollini 1984, Ronnick 1997: 382, Flower 1998.

${ }^{6}$ Champlin 2003: 29-30.

7 Jones, Milns 1984: no. 59-60. For an interesting parallel that illustrates the influence of second century writers, but also for the continuation of some of Domitian's images, see Procopius, Secret History 8.22.

${ }^{8}$ Waters 1964: 57.

9 Wallace-Hadrill 1983: 166; Wallace-Hadrill 1982.

${ }^{10}$ Jones 1992: 196.

${ }^{11}$ Plin., Pan. 49.2, "How much safer is that same house today, and how much happier, now that its master finds protection in popularity instead of cruelty, and seeks the thronging crowd of his people instead of solitude behind locked doors"; cf. Waters 1964: 50, Mooney 1930: 38.

${ }^{12}$ Duff 1964: 511, Townend 1967: 92.

13 Shotter 1993: 8, Mooney 1930: 25.

${ }_{14}$ Plin., Ep. 5.10.2-3, "But you outdo even my doubts and hesitations ... the work is already completed and perfect, for revision will not give it more polish but dull its freshness"; cf. Lounsbury 1979: 65, Carter 1982: 8.
} 
to be an accurate representation of Domitian in accordance with the literary tradition of the period..$^{15}$ This was done by providing a number of different accounts of Domitian's activities. Suetonius presents these accounts in a clear and precise order by dividing the biography into commendable and non-commendable passages so that the readers may draw their own conclusions, ${ }^{16}$ but with the omnipresent guidance of the author. It must be acknowledged that the passages Suetonius has written that purport to be positive accounts of Domitian are also filled with criticism, however much of the criticism is cushioned by positive representations of the emperor.

In several literary sources from this period the construction of a negative image is produced by first complimenting the individual so that when his negative aspects are introduced his previously mentioned positive points serve to accentuate his negative characteristics. ${ }^{17}$ One of the most obvious aspects of this literary tradition is the concept of an individual's nature being essentially static; inherently 'good' or 'bad'. ${ }^{18}$ This concept can be seen in Suetonius' introductory criticisms of Domitian's vita, where he states that Domitian possessed a wicked nature even in his youth. ${ }^{19}$ Evidence can also be found in other biographies by Suetonius including the Life of Nero: Pluris e familia cognosci referre arbitror, quo facilius appareat ita degenerasse a suorum virtutibus Nero, ut tamen vitia cuiusque quasi tradita et ingentia rettulerit. ${ }^{20}$

The Life of Domitian is unique because it renders a non-commendable account at the beginning before progressing to Domitian's commendable actions and then concluding with another disreputable section that finishes with an account of the emperor's death. ${ }^{21}$ Suetonius' condemnations of Domitian are subtler than the works of other authors of the period, ${ }^{22}$ which may have proved a more effective method for portraying the emperor in a negative light. ${ }^{23}$ Although subtle, Suetonius reveals his opinion through ensuring that his non-commendable account of Domitian's activities dominates his condemnations. This maintains the appearance of objectivity to the reader because Suetonius does not viciously attack the emperor and presents both good and bad accounts. However, Suetonius' pretence of impartiality (if there is such a thing) lacked substance due to his adoption of opinions from the prevailing literary tradition, and his tendency to include negative representations of Domitian even in passages he claims are praising the emperor. ${ }^{24}$ Suetonius' clever compilation of Domitian's positive and nega-

\footnotetext{
${ }^{15}$ Lloyd 1969: 299.

${ }^{16}$ Bradley 1978: 14.

17 Brunt 1961: 221.

${ }^{18}$ Warmington 1977: 6.

${ }^{19}$ Suet., Dom. 1.1.

${ }^{20}$ Suet., Nero 1.2, "It seems worthwhile to give an account of several members of the family, to exhibit more clearly that though Nero degenerated from the good qualities of his ancestors, he still reproduced the vices of each, as if transmitted by natural inheritance to him"; cf. Nero 26.1, 43.1.

${ }^{21}$ Jones 1996: XV.

22 Syme 1958: 502, Vinson 1989: 433; for examples see Juv. 2.30-1; Plin., Pan. 52.3.

${ }^{23}$ Ahl 1984: 178.

${ }^{24}$ Waters 1964: 51, Lounsbury 1979: 15.
} 
tive characteristics creates a definite representation whereby the possibility for his freedom from guilt is difficult to perceive..$^{25}$

Suetonius deals with the non-commendable actions of Domitian's youth in chapters one to three, where the beginning statements outline Suetonius' hostile attitude towards the deceased emperor. Disregard for Domitian begins in the second sentence of the text when Suetonius comments that: pubertatis ac primae adulescentiae tempus tanta inopia tantaque infamia gessisse fertur, ut nullum argenteum vas in usu haberet (Dom. 1.1. "He is said to have passed the period of boyhood and early youth in great poverty and infamy"). ${ }^{26}$ Suetonius follows this statement with an allegation that Domitian's family was so poor that they had no 'silver plate' and that he had prostituted himself to Claudius Pollio and Nerva, allowing himself to be sodomised at the age of seventeen and being guilty of infamia. The disgust that an allegation like this would create amongst Suetonius' readers can be seen in the success of a similar accusation by Cicero against Antony; the same defamatory effect was desired when Cicero claimed: Primo uulgare scortum, certa flagitii merces, nec ea parua: sed cito Curio interuenit, qui te (Antonium) a meretrico quaestu abduxit et, tamquam stolam dedisset, in matrimonio stabili et certo collocauit. ${ }^{27}$ Suetonius continues his negative appraisal of Domitian by referring to his escape from Vitellius' legions in AD 69 (by mingling within a procession of Isaic priests) as an act of cowardice. $^{28}$ Suetonius' apparent disapproval of the Isis cult also casts a slur on Domitian because he was renown for his extravagant devotion to a cult, found unacceptable to many conservative people within Roman society. ${ }^{29}$ Suetonius' portrayal of Domitian's 'cowardice' becomes an allegation of political illegitimacy and greed when Suetonius recounts the irresponsible actions of Domitian when he claims the title of Caesar and proceeds to behave recklessly..$^{30}$

Suetonius' hostility toward Domitian can be seen in his writing: Post victoriam demum progressus et Caesar consalutatus honorem praeturae urbanae consulari potestate suscepit titulo tenus, nam iuris dictionem ad collegam proximum transtulit, ceterum omnem vim dominationis tam licenter exercuit, ut iam tum qualis futurus esset ostenderet (Dom. 1.3. "It was only after the victory that he ventured forth and after being declared Caesar, he took the office of urban praetor with consular power, but only in name, turning over all legal business to his next colleague. But he exercised all the tyranny of his position so lawlessly that it was even then apparent what kind of a man he was to be"). ${ }^{31}$ This demonstrates the negative representation that Suetonius accords Domitian throughout the account of his life. ${ }^{32}$ Following this statement Suetonius describes Domitian's behaviour as vile and seditious, claiming that he seduced married women and distrib-

\footnotetext{
${ }^{25}$ Goodyear 1972: 46.

${ }^{26}$ See also Jones, Milns 2002: 122.

${ }^{27}$ Cic., Phil. 2.44. "First you were a common prostitute, the fees for your infamies were fixed, and they were not small; but Curio quickly arrived, who took you from your meretricious traffic, and, as if he had given you the robe of a matron, set you up in a lasting and stable marriage".

${ }^{28}$ Suet., Dom. 1.2; Jones 1996: 15-6.

${ }^{29}$ Witt 1971: 86; Juv. 6.526; Ov., Am. 2.2.25; cf. Stewart 1994.

30 Suet., Dom. 1.3; Jones 1996: 16

31 See Jones, Milns 2002: 122-3.

32 Suet., Dom. 1.3.
} 
uted an excessive number of governmental positions without proper authority or guidance. Suetonius then depicts Domitian's father, Vespasian, as unimpressed by Domitian's actions.

Chapter two begins with an account of Domitian's behaviour during the expedition against Gaul and the Germanies. Suetonius depicts Domitian as impulsive and immature, with a passion for fame. ${ }^{33}$ Titus (Domitian's older brother), who was celebrating a joint military triumph with his father, is portrayed as Vespasian's competent and favourite child, whereas Domitian is portrayed as undeserving of military prestige. ${ }^{34}$ Domitian's desire for military recognition is likely to be exaggerated, although such a desire would have been expected considering the military achievements of his relatives. ${ }^{35}$ The contrast between Domitian and his brother is a constant theme throughout all of the Flavian Vitae, in which accolades for Titus' actions and skills are the antithesis of attitudes towards Domitian. A good example of this is Suetonius' comment that Titus: imitarique chirographa quaecumque vidisset, ac saepe profiteri maximum falsarium esse potuisse. ${ }^{36}$ Such a skill would have received a different portrayal if it was a reference to Domitian. ${ }^{37}$

Suetonius' assertion that Titus relinquished one of his ordinary consulships for Domitian is also false because Domitian's father and brother were not candidates due to their censorships in AD 73. The malevolent authorial intentions of Suetonius are thereby exhibited. ${ }^{38}$ Suetonius continues in this critical fashion by bringing the nature of Domitian's poetic interests into disrepute: simulavit et ipse mire modestiam in primisque poeticae studium, tam insuetum antea sibi quam postea spretum et abiectum, recitavitque etiam publice (Dom. 2.2. "He made a notable pretence of modesty and particularly an interest in poetry, an art that had previously been unfamiliar to him as it was later despised and thrown away, and he even gave readings in public" $).{ }^{39}$ Other ancient literary sources including Quintilian, Statius, the elder Pliny and Silius Italicus refer to Domitian's passion for poetry as worthy of praise. ${ }^{40}$ Only Tacitus and Suetonius bring this aspect of Domitian's personality into disrepute, with Tacitus commenting: Domitianus sperni a senioribus iuventam suam cernens modica quoque et usurpata antea munia imperii omittebat, simplicitatis ac modestiae imagine in altitudinem conditus studiumque litterarum et amorem carminum simulans, quo velaret animum et fratris se aemulationi subduceret, cuius disparem mitoremque naturam contra interpretabatur. ${ }^{41}$ Suetonius later admitted that Domitian libe-

\footnotetext{
33 Suet., Dom. 2.1.

${ }^{34}$ Jones 1996: 21.

${ }^{35}$ Tac., Hist. 3.44; Jones 1996: 19.

${ }^{36}$ Suet., Tit. 3. "He could imitate any handwriting that he had seen and frequently declared that he could have been the prince of forgers".

${ }^{37}$ Duff 1964: 526.

38 Suet., Dom. 2.1.

39 See Jones, Milns 2002: 125.

${ }^{40}$ Quint., Decl. 10.1.91; Plin., Nat. praef. 5; Stat., Ach. 1.15-6; Sil. 3.619.

${ }^{41}$ Tac., Hist. 4.86. "When Domitian realized that his elders treated his youth with contempt, he abandoned exercising all imperial duties, even those of a trifling character and tasks that he had done before, then, under the guise of simplicity and moderation, he gave himself over to profound dissimulation, pretending
} 
ralia studia imperii initio neglexit, quanquam bibliothecas incendio absumptas impensissime reparare curasset, exemplaribus undique petitis missisque Alexandream qui describerent emendarentque (Dom. 20. "At the start of his rule he neglected liberal studies, although he provided for having the libraries, which were destroyed by fire, renewed at great expense, seeking copies from everywhere of the lost works, and sending scribes to Alexandria to transcribe and correct them"). This, together with the high cost of replacing manuscripts with little popular appeal implies a genuine interest on Domitian's part.

Suetonius goes on to suggest that Domitian considered challenging his brother for the conferral of imperial powers after Vespasian's death. ${ }^{42}$ Domitian is then depicted as: neque cessavit ex eo insidias struere fratri clam palamque, quoad correptum gravi valitudine, prius quam plane efflaret animam, pro mortuo deseri iussit; defunctumque nullo praeterquam consecrationis honore dignatus, saepe etiam carpsit obliquis orationibus et edictis (Dom. 2.3. "And from then on he never stopped plotting against his brother secretly and openly, until Titus was taken with a dangerous illness, when Domitian ordered that he be left for dead having not drawn his final breath. And after his passing he bestowed no honour upon him, apart from deification, often assailing his memory in ambiguous phrases, both in his speeches and edicts"). ${ }^{43}$ Domitian was left in a tenuous position after Vespasian's death because of the possibility of Titus having an heir and thereby negating any imperial prospects for Domitian. ${ }^{44}$ However, the assertion that Domitian did not bestow any posthumous honours upon his brother is misleading given that he commemorated him on his coinage ${ }^{45}$ and dedicatory inscriptions, ${ }^{46}$ erected the Templum Gentis Flaviae, the Arcus Titi, the Templum Vespasiani et Titi and an aedes to Titus in the Templum Divorum. ${ }^{47}$ Such evidence refutes Suetonius' claims and demonstrates the bias in his commentary.

Chapter Two is concluded with Suetonius depicting Domitian's reclusive and anti-social nature as secretive and scheming, reflecting an untrustworthy nature. ${ }^{48}$ This imagery can also be seen in the writings of other authors who covered the period, ${ }^{49}$ such as Aurelius Victor. ${ }^{50}$ Suetonius continues his bias against Domitian in the final sentence of this section, stating that Domitian was essentially evil in nature and had few redeeming qualities: Circa administrationem autem imperii aliquamdiu se varium praestitit, mixtura quoque aequabili vitiorum atque virtutum, donec virtutes quoque in vitae deflexit; quantum coniectare licet, super ingenii naturam inopia rapax, metu saevus (Dom., 3.2. "In his administration of the Empire for some time he showed himself to be inconsistent, with

to have a devotion to literature and a love of poetry to hide his real character and to withdraw before his brother's rivalry, on whose milder nature, completely unlike his own, he put a bad construction".

${ }^{42}$ Suet., Dom. 2.2.

${ }^{43}$ See Jones, Milns 2002: 126.

44 Jones 1996: 27.

${ }^{45}$ Mattingly 1966: n. 2.313.

${ }^{46}$ CIL 6.943-6.

${ }^{47}$ Packer 2003: 174, Anderson 1983: 95-7, Hammond 1959: 206; cf. Garthwaite 1993: 80.

48 Suet., Dom. 3.1

${ }^{49}$ Dio 66.9.4-5; Tac., Ag. 39.3; Plin., Pan. 48.5, 49.2, 49.6.

${ }^{50}$ Aurelius Victor, De Caesaribus 11.5. 
an equal number of virtues and vices, but finally he turned his virtues also to vices; for as far as can be guessed, it was contrary to his natural character that he was made rapacious through need and cruel by fear"). ${ }^{51}$ The positive benefactions and administration of Domitian are later expanded in more detail by Suetonius, particularly at the beginning of chapters nine and eleven, but this served as a comparison to his negative 'natural disposition' referred to here. ${ }^{52}$

Chapters four to nine constitute the commendable section of Suetonius' Domitian. The fourth chapter begins with the phrase: Spectacula assidue magnifica et sumptuosa edidit non in amphitheatro modo, verum et in Circo, ubi praeter sollemnes bigarum quadrigarumque cursus proelium etiam duplex, equestre ac pedestre, commisit; at in amphitheatro navale quoque (Dom., 4.1. "He regularly gave grand and expensive entertainments, both in the amphitheatre and circus, where as well as the usual races between two-horse and fourhorse chariots, he also exhibited two battles, one between infantry forces and the other by cavalry; and he even gave a naval battle in the amphitheatre"), ${ }^{53}$ providing an image of Domitian rather as a spendthrift than as a benefactor with excessive tastes for grandeur and indulgence, with sumptuosa given emphasis by the author. ${ }^{54}$ This use was similar to his reference in the Life of Nero to the great expense of constructing the harbour..$^{55}$ In the Life of Domitian Suetonius continues in this fashion throughout the chapter as he details the extravagant games, literary contests and immoderate presentations of money and feasts to the common people indulged in by Domitian. ${ }^{56}$ Suetonius points out that the public financed all of these expenses, and claims Domitian's motive as personal glory, emphasized by the Greek style of dress that he adopted which was also worn by the flamen Dialis at the competitions. ${ }^{57}$ This is not entirely the case as Suetonius neglects to mention that the games provided by the quaestors were paid for by them and were publicly-financed outlays not unique to the reign of Domitian. ${ }^{58}$ The emphasis placed upon Domitian's expenses is further accentuated by Suetonius' account of Domitian's building program when he alleges that Domitian desired to claim glory for himself by restoring damaged buildings and placing only his own name in the inscriptions on the restored buildings. ${ }^{59}$ Domitian actually inscribed Domitianus ... restituit on the buildings he restored. ${ }^{60}$ Suetonius later claims that the restoration of buildings was just another example of Domitian's wasting of public finances, which later led to imperial financial difficulties. ${ }^{61}$

Not surprisingly given the nature of the genre, Suetonius' account of Domitian's military campaigns is far from comprehensive, the revolt of Saturninus was the only

\footnotetext{
51 See Jones, Milns 2002: 128.

52 For further discussion see Jones 1996: 33-4.

${ }^{53}$ See Jones, Milns 2002: 129.

${ }^{54}$ Jones 1996: 35.

55 Suet., Nero 9.1.10.

${ }^{56}$ Suet., Dom. 4.1-5.

${ }^{57}$ Suet., Dom. 4.4.

58 Jones 1996: 35.

59 Suet., Dom. 5.1

${ }^{60}$ McCrum, Woodhead 1966: n. 422, 436.

${ }^{61}$ Suet., Dom. 10.1; Jones 1992: 79.
} 
event worth dealing with in depth. In his account Suetonius claims that Domitian was lucky rather than proficient or worthy of success. Suetonius did observe the merits of Domitian's military campaigns but quoted them as being: expeditiones partim sponte suscepit, partim necessario (Dom., 6.1. "His campaigns were undertaken partly without provocation and partly by necessity").62 Only the Sarmatian campaign is justified in Suetonius' opinion, with the Chattan Wars shown as unprovoked and the Dacian campaigns mentioned so that Domitian can be blamed for the loss of Oppius Sabinus and Cornelius Fuscus. ${ }^{63}$ Suetonius continues to reveal his bias by mentioning Domitian's triumph over the Chatti and Dacians: the two campaigns that Suetonius had previously depicted in a negative light. He does not mention the accolades that Domitian received for these accomplishments in $\mathrm{AD} 83$ or $86 .{ }^{64}$ This assessment of Domitian's military policy, despite being less hostile than Tacitus' appraisal, ${ }^{65}$ is heavily biased and awards no credit to Domitian for the clear and coherent policies to which he was devoted. ${ }^{66}$

Suetonius' comments about Domitian's administrative reforms in chapters seven to nine, (which he deals with in very haphazard fashion) combining the jurisdictional, legislative and religious changes made during his reign. ${ }^{67}$ Suetonius disregards the division between each of the administrative roles played by Domitian, possibly reflecting the princeps attitude towards the reduction of distinction between each specific function. This may also be connected with Domitian's concern about the growing rivalry that existed within the senatorial order. It was for this reason that he exerted greater control over the various appointments that were made and opened up more positions in the imperial court for freedmen. ${ }^{68}$ This indiscriminate attitude towards the allocation of actions to their associated rubrics contrasts with other Flavian Vitae, and does not provide a favourable image of either Domitian or his reforms. Throughout the whole analysis of Domitian's administrative functions Suetonius provides no evidence of his acting through imperial cognitio, and no example of ius ipse dixit. ${ }^{69}$ Despite his low opinion of Domitian's efficiency as an emperor, Suetonius does not deny the fact that Domitian's administrative capabilities were of the highest standard, and states: Magistratibus quoque urbicis provinciarumque praesidibus coercendis tantum curae adhibuit, ut neque modestiores umquam neque iustiores exstiterint; e quibus plerosque post illum reos omnium criminum vidimus (Dom., 8.2. "He took care to restrain the urban magistrates and the governors of provinces that at no time were they more honest or just, whereas after his time we have seen many charged with all types of offences"). Suetonius proceeds to detail the application of public morals, which is mentioned in association with Domitian's assumption of censorial power, and later his appointment as perpetual censor. ${ }^{70}$

\footnotetext{
62 See Jones, Milns 2002: 134-5.

${ }^{63}$ Suet., Dom. 6.1-2.

${ }^{64}$ Suet., Dom. 6.2; Jones 1996: 53.

65 Tac., Hist. 1.2 .

${ }^{66}$ Webster 1969: 69; Viscusi 1973: 71.

${ }^{67}$ Jones 1996: 61.

68 Suet., Dom. 7.2

${ }^{69}$ Jones 1996: 69-71.

70 Suet., Dom. 8.3.
} 
An account of Domitian punishing an equestrian for returning to his wife after divorcing her, and then charging her with adultery, follows. This account is significant because it portrays Domitian as hypocritical because of his divorce from Domitia under similar circumstances. Suetonius then describes Domitian's thorough enforcement of the lex Scantinia ${ }^{71}$ which, considering the allegations concerning his youthful sexual exploits, casts a dubious light on the ensuing punishment of the Vestals. ${ }^{72}$ This slur by Suetonius is unsubstantiated because Domitian was not a puer when the supposed incident with Pollio and Nerva occurred. Domitian was also protected by his status in regard to his eunuch Earinus, making this statement completely unjustified in its placement. According to Suetonius, Domitian's treatment and punishment of the Vestal Virgins for sexual indiscretion was completely appropriate considering that any impropriety of this nature would be incestuous and would dishonour both the state and the gods. ${ }^{73}$ But the positioning of the incident within the context of the preceding image of an hypocritical Domitian, allows this to be seen as a prelude to Domitian's fall into vice, his tendency towards excessive punishment, and his questionable integrity. ${ }^{74}$

The commendable section continues in the ninth chapter where Suetonius mentions that Domitian shrank from bloodshed and would refuse inheritances left to him from those with children. ${ }^{75}$ These praiseworthy activities are implicitly contrasted with his later practice, when Domitian accepts the estates of total strangers ${ }^{76}$ and is depicted as moving towards to vices that are in accordance with his 'natural disposition'. Suetonius concludes this section with reference to Domitian's suppression of informers claiming that: Princeps qui delatores non castigat, irritat (Dom., 9.3 "An Emperor who does not punish informers encourages them"). ${ }^{77}$ This action was subsequently used by Suetonius to emphasize Domitian's hypocrisy and corruption. ${ }^{78}$

The first comment of Suetonius' final condemnatory section begins with a statement that makes his opinion of Domitian completely clear: sed neque in clementiae neque in abstinentiae tenore permansit, et tamen aliquanto celerius ad saevitiam descivit quam ad cupiditatem (Dom.., 10.1. "But he did not continue with this clemency or integrity, although he turned to cruelty more rapidly than to avarice"). This allegation was made in the earlier portions of Suetonius' writings and was also made by other authors of the period, with Tacitus being Domitian's harshest critic. The allegation also features in Suetonius' Vespasian where he claims that the penalty Domitian paid for his cruely was fully deserved. ${ }^{79}$ Suetonius continues by discussing how Domitian complures senatores consulares .... interfecit; an aspect of his policies that was not only seen as entirely unjust by the senatorially-inclined Suetonius, but also immensely exaggerated. ${ }^{80}$ Suetonius uses

${ }^{71}$ Quint., Inst. 4.2.69, 7.4.42; Juv. 2.44; Viscusi 1973: 89.

${ }^{72}$ Suet., Dom. 8.3-4.

${ }^{73}$ Suet., Dom. 8.4-5.

74 Jones 1996: 80.

${ }^{75}$ Suet., Dom. 9.1-2.

${ }^{76}$ Suet., Dom. 12.2.

77 This is also mentioned in Dio 67.1.4.

78 Suet., Dom. 12.1.

79 Suet., Ves. 1.1; Tac., Ag. 3.2; Aurelius Victor 11.3.

${ }^{80}$ Suet., Dom. 10.2; Wallace-Hadrill 1983: 161. 
the deaths of Arulenus Rusticus and Helvidius Priscus the younger (cos. 93) to accentuate the saevitia of Domitian. This term is used in a previous statement whereby Domitian is claimed to be saevus metu, and per haec terribilis cunctis et invisus. ${ }^{81}$ Suetonius neglects to mention that both the deceased had received promotion from Domitian previously. ${ }^{82}$

Suetonius goes on to explain in great detail the extent of Domitian's cruelty; the sudden and unjustified nature of many executions including those of senators, claiming that: erat autem non solum magnae, sed etiam callidae inopinataeque saevitiae (Dom., 11.1. "His savage cruelty was not only excessive, but also cunning and sudden"). Following on from this description of Domitian's supposed senatorial persecution, Suetonius reflects the tradition of damnatio memoriae, claiming that due to Domitian's extravagant expenses the reputed financial straits in which the emperor found himself precipitated further persecutions. ${ }^{83}$ This is not the case because it has been demonstrated that the state's finances at the end of Domitian's reign were balanced, if not quite healthy. ${ }^{84}$ This can be seen in the building program that Domitian enacted which would not have been undertaken if the imperial coffers were empty, no matter how immoderate were Domitian's tastes. ${ }^{85}$ Suetonius' account continues in the same fashion by claiming that as a result of the overdue pay increase that was granted to the legions by Domitian, their diminished numbers had placed the security of the Empire at risk: exhaustus operum ac munerum inpensis stipendioque, quod adiecerat, temptavit quidem ad relevandos castrenses sumptus numerum militum deminuere; sed cum et obnoxium se barbaris per hoc animadverteret neque eo setius in explicandis oneribus haereret, nihil pensi habuit quin praedaretur omni modo (Dom., 12.1-2. "Reduced to financial difficulties because of the expense of his buildings and shows, as well as by the additions that he had paid to the soldiers, he tried to reduce the military expenses by reducing the number of troops; but perceiving that by doing so he exposed himself to the attacks of the barbarians, and nevertheless had difficulty in easing his debts, he had no hesitation in resorting to every kind of robbery"). ${ }^{86}$ This is most likely an exaggeration, there being little evidence to support such a claim. ${ }^{87}$ Domitian may have discouraged or limited recruitment but considering his affection for military exploits and glory this seems unlikely. ${ }^{88}$

Suetonius continues in the thirteenth chapter to illustrate Domitian's arrogance by highlighting how he boasted in the senate that imperium had rightfully been returned to him: principatum vero adeptus neque in senatu iactare dubitavit et patri se et fratri imperium dedisse, illos sibi reddidisse (Dom., 13.1. "When he had become Emperor, he did not wait to boast in the Senate that he had given their power on both his father and brother, and

${ }^{81}$ Suet., Dom. 10.3-4, 14.1 "In this fashion he had become an object of terror and hatred to everyone"; cf. Jones 1979: 41.

82 Jones 1973: 85.

${ }^{83}$ Suet., Dom. 12.2.

${ }^{84}$ Sutherland 1935: 152, Rogers 1984: 78, Jones 1971: 264. See Carradice 1983 for further discussion of Domitian's finances.

${ }^{85}$ Suet., Dom. 5; Plut., Pub. 15; Jones 1992: 79, Anderson 1983: 95.

${ }^{86}$ See Jones, Milns 2002: 150-1.

${ }^{87}$ Plin., Pan. 41.2; Dio 67.3.5.

${ }^{88}$ Jones 1996: 101. 
that they had only returned him his own."). ${ }^{89}$ When this allegation is added to the number of consulships that Domitian held (10 times during his reign), and his ingrained disposition towards the attainment of public honours, the image produced is not favourable. However, Suetonius' opinion is hard to substantiate considering that he had departed from the previous Flavian monopoly of consulships. ${ }^{90}$ His portrayal of Domitian should be compared to the portrayal of Trajan's desire for fame, which was merely an "amiable weakness, not a sign of tyrannical arrogance." ${ }^{91}$ Suetonius goes to great lengths to outline the claims to divinity that Domitian made, exploiting in detail the emperors propensity for gold and silver statues: statuas sibi in Capitolio non nisi aureas et argenteas poni permisit ac ponderis certi (Dom., 13.2. "He suffered no statues to be erected in his honour on the Capitol, except those of gold and silver and of a fixed weight"). This passage is indicative of Suetonius' attempts to substantiate such assertions because a decree to allow only gold and silver statues would have been of the greatest offense..$^{92}$ Not only does this illustrate Domitian's arrogance but also his impiety because of the correlation between gold statues and divinity. ${ }^{93}$ According to the prevailing opinion of Domitian, he did not deserve an association to divinity because of his purportedly incestuous behaviour with Julia Titi.

Domitian's decision to change the names of the months September and October to Germanicus and Domitianus is used by Suetonius to further accentuate Domitian's arrogance, ${ }^{94}$ even though this was a common imperial practice..$^{95}$ Suetonius, in more favourable biographies, deems this to be an honour, with Julius receiving: appellationem mensis e suo nomine, ${ }^{96}$ and Augustus: in cuius ordinatione Sextilem mensem e suo cognomine nuncupauit magis quam Septembrem quo erat natus. ${ }^{97}$ However, in the Life of Domitian this is portrayed as being akin with the emperor's desire for deification, which is mentioned in the previous section. ${ }^{98}$ After his death the original names were restored. ${ }^{99}$

A lengthy description of Domitian's assassination and the preceding events develops through the conclusion of this second condemnatory passage, with the emperor's fear and paranoia coming under scrutiny. Domitian's character is portrayed through the use of such phrases as: quare pavidus semper atque anxius minimis etiam suspicionibus praeter modum commovebatur (Dom., 14.2. "So he was always fearful and worried, and was disquieted beyond measure by even the slightest suspicions"). Suetonius uses Domitian's superstitious nature to explain the emperor's further decline into vice and

\footnotetext{
${ }^{89}$ See also Wallace-Hadrill 1983: 165.

${ }^{90}$ Jones 1973: 81.

${ }^{91}$ Waters 1964: 71.

92 Plin., Pan. 52.1-6; Whitehorne 1975: 117.

${ }^{93}$ Whitehorne 1975: 118.

${ }^{94}$ Suet., Dom. 13.3. See also Plin., Pan. 54.

95 Suet., Tib. 26.2, Cal. 15.2, Nero 55.

${ }^{96}$ Suet., Jul. 76.1. "The naming of one of the months by his name."

${ }^{97}$ Suet., Aug. 31.2. "In making this arrangement he called the month Sextilis his own cognomina rather than his month of his birth September."

98 Suet., Dom. 13.2-3. For further discussion of this see Jones 1996: 114-15, Coleman 1988: 80

${ }^{99}$ Macr., Sat. 1.36-7; Plut., Numa 19.4.
} 
cruelty and to justify his assassination. ${ }^{100}$ Suetonius (who was superstitious himself) uses Domitian's superstition to explain his execution of Flavius Clemens, stating that Domitian: denique Flavium Clementem patruelem suum contemptissimae inertiae, cuius filios etiam tum parvulos successores palam destinaverat abolitoque priore nomine alterum Vespasianum appellari, alterum Domitianum, repente ex tenuissima suspicione tantum non in ipso eius consulatu interemit (Dom., 15.1. "Finally he executed his cousin Flavius Clemens, suddenly and on a very minor suspicion, almost before the end of his consulship; and yet Flavius was a man of the most contemptible laziness and Domitian had publicly named his sons as his successors, who were very young at the time, changing their previous names, naming one Vespasian and the other Domitian.").

Suetonius describes the extent of the opposition to Domitian's regime, with the notable absence of Trajan and Hadrian. ${ }^{101}$ Suetonius' portrayal of Domitian's physical appearance as grandibus oculis, verum acie hebetiore..... postea calvitio quoque deformis et obesitate ventris et crurum gracilitate, quae tamen ei valitudine longa remacruerant (Dom., 18.12. "His eyes were large, but his sight was somewhat dim...in later life he had the further disfigurement of baldness, a protruding stomach, and spindly legs, though the latter had become thin after a drawn out illness"), is a sign of the low esteem in which Suetonius held Domitian. ${ }^{102}$ Suetonius had a particular interest in the physical being and published a book De vitiis corporalibus, which dealt with parts and weaknesses of the human body. ${ }^{103}$ Suetonius' assessment of Domitian's physique and the reflection upon his character was a popular style of evaluation in the period and may indicate Suetonius' desire to further his evaluation of Domitian's character. ${ }^{104}$

Suetonius' Life of Domitian establishes a bias against Domitian that pervades the work in its entirety. Suetonius avoided many of the emotional statements used by his contemporaries, ${ }^{105}$ instead choosing to adopt a more subtle approach to his writing. His negative approach to the Emperor Domitian can be attributed to two other factors. Firstly, in view of his close patron-client relationship with Pliny the Younger, ${ }^{106}$ he was probably greatly influenced by his patron who was passionate and public about his antiDomitianic views. Secondly, at the time of writing, Domitian was the most recent of the deceased emperors who were able to be written about ${ }^{107}$ and for this reason was likely to be the most interesting to Suetonius' audience. Only twenty odd years had passed between the death of Domitian and the production of Suetonius' first Imperial lives (AD 119-21). This vita would have been written after the retirement of Suetonius as ab epistulis, but the reign of Domitian would have still been fresh in the memory of many members of his audience.

\footnotetext{
${ }^{100}$ For further discussion see Southern 1997: 120, Adams 2004.

101 Jones 1996: 116.

102 This was similar to the descriptions of other unacceptable Emperors, such as Gaius (Suet., Cal. 50.1) and Claudius (Suet., Cl. 30). See also Evans 1935: 62, Gascou 1976.

${ }^{103}$ Evans 1935: 62, Morgan 1997.

104 Wardman 1967: 414.

105 Mooney 1930: 19.

106 Plin., Ep. 1.18, 3.8, 5.10, 10.94.

107 The Lives of Nerva and Trajan were probably 'too close for comfort' during the period in which Suetonius was writing, being the direct predecessors of the Emperor Hadrian.
} 
When compared to the other authors of this period it is possible that Suetonius' relatively subtle writing style may indicate some appreciation for Domitian's reign, but the socio-political climate of the time would have made any favourable treatment of Domitian difficult. This is because the emperors following the end of the Flavian dynasty (Nerva, Trajan and Hadrian) had all tried to distance themselves from their Flavian predecessors. Because of these factors and any personal bias that he held, Suetonius conveys a negative, hostile bias in his writing, which affects even the laudable aspects of Domitian's reign.

Despite his obvious hostility toward Domitian, Suetonius has belittled the meritorious achievements of the emperor's career, but his treatment of these incidents must be treated thoughtfully. ${ }^{108}$ By the time Suetonius wrote this vita he had already become a noted author, and in view of this maturity, he would naturally have developed a set of ideals and opinions that are apparent within his works. ${ }^{109}$ In regard to the extant literary evidence, Suetonius has belittled Domitian in his portrayal, as did other prejudiced sources, such as Tacitus and Pliny, making their assessment of Domitian's character considerably distorted. ${ }^{110}$

Dr. Geoff W. Adams

School of Classics, History and Religion

The University of New England, Australia

E-mail: gadams5@pobox.une.edu.au

108 Baldwin 1983: 296.

109 Wallace-Hadrill 1983: 8.

110 Jones 1992: 196. 


\section{References}

Adams, G. W. (2004) 'Emperor Domitian and the Temple Construction.' - Anistoriton 8.E043 (http://www.anistor.co.hol.gr/index.htm).

Ahl, F. (1984) 'The Art of Safe Criticism in Greece and Rome.' - AJPh 105, 174-208.

Anderson, J. C. (1983) 'A Topographical Tradition in Fourth Century Chronicles: Domitian's Building Program.' - Historia 32, 93-105.

Baldwin, B. (1983) Suetonius. Amsterdam: Hakkert.

Bradley, K. R. (1978) Suetonius' Life of Nero: An Historical Commentary. Bruxelles: Latomus.

Brunt, P. A. (1961) 'Charges of Provincial Maladministration.' - Historia 10, 189-227.

Carradice, I. (1983) Coinage and Finances in the Reign of Domitian. BAR International Series 178, Oxford: Oxford University Press.

Carter, J. M. (1982) Suetonius: Divus Augustus. Bristol: Bristol Classical Press.

Champlin, E. (2003) Nero. Cambridge, Mass.: Harvard University Press.

Coleman, K. M. (1988) Statius Silvae IV. Oxford: Oxford University Press.

Duff, A. M. (1964) A Literary History of Rome in the Silver Age. London: Benn.

Evans, E. C. (1935) 'Roman Descriptions of Personal Appearance in Roman History and Biography.' - Harvard Studies in Classical Philology 46, 43-84.

Flower, H. I. (1998) 'Rethinking “Damnatio Memoriae”: the case of Cn. Calpurnius Piso Pater in AD 20.' - Classical Antiquity 17.2, 155-186.

Garthwaite, J. (1993) 'The Panegyrics of Domitian in Martial Book 9.' - Ramus 22.1, 78-102.

Gascou, J. (1976) 'Suétone et l'ordre équestre.' - REL 54, 257-277.

Goodyear, F. R. D. (1972) The Annals of Tacitus: Books 1-6. Vol. 1, Cambridge: Cambridge University Press.

Hammond, M. (1959) The Antonine Monarchy. Rome: American Academy in Rome.

Jones, B. W. (1971) 'Preparation for the Principate.' - PP 26, 264-270.

Jones, B. W. (1973) 'Domitian's Attitude to the Senate.' - AJPh 94.1, 79-91.

Jones, B. W. (1979) Domitian and the Senatorial Order. Philadelphia: American Philosophical Society.

Jones, B. W. (1992) The Emperor Domitian. London: Routledge.

Jones, B. W. (1996) Suetonius: Domitian. Bristol: Bristol Classical Press.

Jones, B. W., Milns, R. D. (1984) The Use of Documentary Evidence in the Study of Imperial History. Sydney: Sydney University Press.

Jones, B. W., Milns, R. D. (2002) Suetonius: the Flavian Emperors. Bristol: Bristol Classical Press.

Lindsay, H. (1994) 'Suetonius as ab epistulis to Hadrian and the early history of the Imperial Correspondence.' - Historia 43, 454-468.

Lloyd, J. O. (1969) Books in Suetonius' De Vita Caesarum. Ann Arbor.

Lounsbury, R. C. (1979) The Art of Suetonius. Diss. Austin.

Mattingly, H. (1966) Coins of the Roman Empire in the British Museum. Vol. 2: Vespasian to Domitian. London: British Museum.

McCrum, M., Woodhead, A. G. (1966) Select Documents of the Principates of the Flavian Emperors. Cambridge: Cambridge University Press. 
McDermott, W. C., Orentzel, A. E. (1979) Roman Portraits: The Flavian-Trajanic Period. Columbia, Mo.: University of Missouri Press.

Millar, F. (1977) The Emperor in the Roman World. London: Duckworth.

Mooney, G. W. (1930) C. Suetoni Tranquilli De Vita Caesarum Libri VII-VIII. London: Longmans.

Morgan, L. (1997) 'Achilleae Comae: Hair and Heroism According to Domitian.' - CQ 47, 209-214.

Packer, J. E. (2003) 'Plurima et Amplissima Opera; Parsing Flavian Rome.' - A. J. Boyle and W. J. Dominik (eds.), Flavian Rome: culture, image text. Leiden: Brill, 167-198.

Pollini, J. (1984) 'Damnatio Memoriae in Stone: Two Portraits of Nero Recut to Vespasian in American Museums.' - AJA 88, 547-555.

Rogers, P. M. (1984) 'Domitian and the Finances of State.' - Historia 33, 60-78.

Ronnick, M. V. (1997) 'Res Gestae 25: Damnatio Memoriae as a Strategy of Rhetoric.' Maia 49.3, 381-384.

Shotter, D. (1993) Suetonius: Lives of Galba, Otho and Vitellius. Warminster: Bristol Classical Press.

Southern, P. (1997) Domitian: Typical Tyrant. London: Routledge.

Stewart, R. (1994) 'Domitian and Roman Religion: Juvenal, Satires Two and Four.' TAPA 124, 309-332.

Sutherland, C. H. V. (1935) 'The Imperial Treasury at the Death of Domitian.' - JRS 25, 150-162.

Syme, R. (1958) Tacitus. Oxford: Oxford University Press.

Townend, G. (1967) 'Suetonius and his Influence.' - T. A. Dorey (ed.), Latin Biography. London: Routledge, 79-111.

Vinson, M. P. (1989) 'Domitia Longina, Julia Titi and the Literary Tradition.' - Historia $38,431-450$.

Viscusi, P. L. (1973) Studies on Domitian. Diss. Delaware.

Vittinghoff, F. (1936) Der Staatsfeind in der römischen Kaiserzeit. Untersuchungen zur "damnatio memoriae". Berlin: Junker und Dünnhaupt.

Wallace-Hadrill, A. (1982) 'Civilis Princeps: Between Citizen and King.' - JRS 72, 32-48.

Wallace-Hadrill, A. (1983) Suetonius: The Scholar and his Caesars. London: Duckworth.

Wardman, A. E. (1967) 'Description of Personal Appearance in Plutarch and Suetonius: The Use of Statues as Evidence.' - CQ 17, 414-420.

Warmington, B. H. (1977) Suetonius: Nero. Bristol: Bristol Classical Press.

Waters, K. H. (1964) 'The Character of Domitian.' - Phoenix 18, 49-77.

Webster, G. (1969) The Roman Imperial Army. London: Black.

Whitehorne, J. E. G. (1975) 'Golden Statues in Greek and Latin Literature.' - GER 22, 109-119.

Witt, R. E. (1971) Isis in the Greco-Roman World. London: Thames and Hudson.

Wood, S. (1983) 'A Too-Successful Damnatio Memoriae: Problems in Third century Roman Portraiture.' - AJA 87, 489-496. 